Pplk. Ing. Pavel Otř́isal, Ph.D., MBA

Vnímání bezpečnostních hrozeb v oblasti CBRN historie a výzvy

Vojenské rozhledy, 2013, roč. 22 (54), č. 1, s. 46-64, ISSN 1210-3292

\title{
Perception of Security Threats in the CBRN Sphere: History and Challenges
}

\section{Abstrakt:}

Období počátku 21. století je typické stavem, který je charakterizován minimalizací vzniku globálního konfliktu a poklesem rizika přmé vojenské agrese mezi státy. Nicméně výskyt a stálá existence zbraní hromadného ničení a náhodné, lidskou činností nebo př́rodními katastrofami způsobené úniky průmyslových nebezpečných látek se stále jeví jako celosvětový problém, který do značné míry omezuje nejenom činnost obyvatelstva, ale i vojsk. Hrozba jejich použití nebo zneužití sílí v době, kdy se značně zvýšilo nebezpečí související s činností teroristických skupin v některých regionech světa, a to i ve zdánlivě technologicky nerozvinutých zemích.

\section{Abstract:}

The period of the beginning of the 21st century is typical for the situation characterized by minimization of a global conflict and by decreasing risks of a direct aggression among neighbouring countries. Nonetheless, the occurrence and permanent existence of mass destruction weapons and industrial accidents caused by human beings, natural disasters produced by leakages of toxic industrial materials, are considered as a global problem that determinates not only the activities of national armies, but also activities of civil population. The danger of WMD deployment is especially high at time of danger, when forces are to be used or misused, and terrorist activities might multiply in some world's regions, even in technologically underdeveloped countries.

\section{Klíčová slova:}

Ochrana osob, zbraně hromadného ničení, CBRN, průmyslové nebezpečné látky, prostředky individuální ochrany, hrozba, riziko.

Key words:

Personnel protection, weapons of mass destruction, CBRN, toxic industrial materials, individual protective equipment, threat, risk. 


\section{Úvod}

Šiření (proliferace) zbraní hromadného ničení (ZHN) zůstává stále jednou z největších globálních hrozeb současnosti. Je trvale prokazována zvýšená snaha některých států (např. Írán, Severní Korea atp.) a nestátních aktérů (al-Ká’idy) tyto zbraně získat. Z hlediska šíření ZHN jsou nejrizikovějšími oblastmi Blízký a Střední východ a jižní a východní Asie. Šírení ZHN je usnadněno rostoucí dostupností znalostí a poznatků, technologií, materiálů dvojího užití a mobilitou vědců. Pro Českou republiku vyvstala nutnost hledat způsoby, jak zajistit svou bezpečnost pro př́pad svého ohrožení ZHN či konvenčními zbraněmi za využití jejich různých nosičů, zejména ve vztahu k ochraně kritické infrastruktury a objektů důležitých pro obranu státu (ODOS).

Vstup do Severoatlantické aliance zásadním způsobem ovlivnil zahraniční i vojenskou politiku ČR. V mezidobí došlo k řadě událostí, na které je třeba neustále reagovat a vyhodnocovat je. Tato doba, v historii NATO zcela určitě významná, byla poznamenána zásadními politicko-vojenskými a politicko-strategickými událostmi, které ovlivnily vnímání hrozeb, a to např́č celým globalizovaným světem. Tyto události se dotkly a ovlivnily řadu politických i bezpečnostních dokumentů nejen aliančních a evropských, ale i dokumentů v působnosti ČR, jejichž vývoj v čase je v textu částečně naznačen. [1]

\section{Záměny hrozeb a rizik}

Studiem bezpečnostních dokumentů lze vysledovat jistou rozporuplnost v chápání a především neujasněnosti v př́stupu $\mathrm{k}$ pojmům bezpečnostní hrozba a riziko. $\mathrm{V}$ zásadě lze ale konstatovat, že současné vnímání těchto pojmů doznalo jednotného chápání a že prakticky nedochází k jejich vzájemnému nepochopení. Srovnáme-li počátek 90. let minulého století se současností, je možné spatřovat výrazný rozdíl. Dnes nikdo nepovažuje proliferaci ZHN za riziko (ačkoli se $\mathrm{v}$ roce 1991 vyskytoval pojem „riziko jaderného terorismu“), hovoří se o ní jednoznačně jako o nejvážnější bezpečnostní hrozbě počátku 21. století. $\mathrm{V}$ té době byly již konkrétní vojenské zkušenosti s válkou v Perském zálivu z roku 1991, kdy se velmi často psalo a hovořilo o tom, že Irák by svými ZHN mohl zasáhnout především Izrael, ale možná i některé státy jižní Evropy. $\mathrm{Z}$ pohledu těchto zemí se v žádném případě nejednalo o riziko. Šlo naopak o přímou a záměrnou hrozbu vojenského charakteru. Navíc průběh této války a její výsledek daly jasné poučení, že kdyby býval Saddám Husajn měl v té době arzenál jaderných zbraní, pak operace Pouštní bouře nemohla proběhnout tak, jak proběhla, protože spojenecká vojska by bývala byla vystavena přímé, záměrné vojenské hrozbě jaderných úderů a nikoli jejich riziku. [2] Vyjádření podmiňovacím způsobem ukazuje na to, že faktický důkaz pravděpodobně neexistuje. Některé z těchto skutečností však byly potvrzeny americkými odborníky, kteří řekli, že , [Saddám] udělal největší chybu, když do Kuvajtu vpadl ještě v době, kdy neměl jaderné zbraně - jinak by se bývala Amerika neopovážila se mu postavit“. [3] Pokud jsou rozdíly mezi USA a tzv. novou Evropou na jedné straně a tzv. starou Evropou na straně druhé, pak se vedou o to, do jaké míry je tato hrozba naléhavá a jak je potřeba jí čelit.

Mezi nejvážnější hrozby pro země v euroatlantické oblasti, které jsou zařazeny do kategorie vojenských hrozeb, tedy patří proliferace ZHN. Tato hrozba působí ve dvou 
hlavních směrech. Prvním je vývoz a rozšiřování zařízení, technologií a know-how k výrobě jaderných, chemických, biologických a bakteriologických zbraní nebo řízených střel. Druhým směrem je pak tajné a pokoutní úsilí některých států o dosažení schopnosti vyrábět tyto zbraně. Jedná se zejména o štěpné materiály, termojaderné zbraně, radioaktivní materiály, biologické zbraně a chemické zbraně. Zvlášt' obávanou hrozbou je šíření nosičů, zejména pak balistických řízených střel, které ZHN dávají maximální vojenské, strategické a psychologické účinky. [4]

Na počátku 21. století se vojenská strategie zaměřuje především na výzkum zásad vedení ozbrojeného zápasu a na studium jejich forem a podob s tím, že se nelze obejít bez důkladného studia zkušeností a poučení ze čtyř velkých válek, které proběhly v tzv. postkonfrontačním období, tedy v období po ukončení studené války. Jedná se operace Pouštní bouře (1991), Spojenecká síla (1999), Trvalá svoboda (2001) a Irácká svoboda (2003). Stranou zájmu strategického myšlení v současné době nezůstává ani využití možností, které jsou uváděny v tzv. „revoluci ve vojenských záležitostech“ (revolution in military affairs). Jejich využití je zkoumáno jako výsledek těsného vzájemného propojení mezi politikou (bezpečnostní politikou) a využíváním nových vědeckých poznatků pro formy vedení ozbrojeného zápasu. [5]

Výsledkem takového propojení je z hlediska řešené problematiky: [6]

$\square$ nové, efektivnější uspořádání ozbrojených sil, které bude maximálně vyhovovat požadavkům soudobých operací,

$\square$ nové způsoby řízení ozbrojených sil a nové metody jejich bojové přípravy s cílem maximálně přizpůsobit jejich vycvičenost ke zvládání nových hrozeb, se kterými se v soudobých operacích mohou setkat,

výrazná převaha v logistice, ale především,

$\square$ nejvyšší možné zajišt'ování ochrany vlastních vojsk, a to především v oblasti ochrany sil před účinky radioaktivní, biologické či chemické kontaminace.

\section{Zkušenosti z použití ZHN ve významných operacích}

Použití zbraní hromadného ničení a zneužití průmyslových nebezpečných látek (PNL) v historii je nesporným faktem. [7-9] Z hlediska chápání současných bezpečnostních hrozeb souvisejících s jejich použitím je pro pochopení východisek, která bezesporu sloužila jako základ pro tvorbu oficiálních bezpečnostních dokumentů ČR, možné provést detailnější rozbor vybraných vojenských operací, který je uveden dále.

Operace Pouštní bouře se odehrávala po ukončení studené, tedy v roce 1991. Irácko-íránská válka prošla několika klíčovými etapami. V roce 1984 se stal velice závažný incident v podobě nasazení ZHN ze strany Iráku. Ve snaze zastavit íránský postup k dálnici Basra-Bagdád byly použity jedovaté plyny. Irácko-íránská válka skončila zejména pro Irák těžkými ztrátami. Na straně Iráku v této době bylo několik závažných negativ. Vědělo se o krutých metodách jeho diktátorského vládce, byl v této válce agresorem a navíc v době nepříznivého vývoje konfliktu proti íránským vojskům použil ZHN. Přesto však, jak hodnotí Lawrence Freedman, profesor válečných studií na King's College London, v této etapě „všechny západní státy bez výjimky měly s Irákem dobré vztahy a vůbec nedávaly najevo znepokojení nad Iráckými ZHN“. [10] 


\subsection{Operace Pouštní bouře}

V průběhu operace Pouštní bouře se agrese Saddáma Husajna do Kuvajtu stala fatální. Jeho hazardní agrese do Kuvajtu měla zničující dopad i na irácký arzenál ZHN. V důsledku operace Pouštní bouře byly spojeneckými vojsky vážně narušeny možnosti Iráku vyvíjet, vyrábět a nasazovat chemické zbraně.

Během operace Pouštní bouře uskutečnila spojenecká vojska přibližně 970 vzdušných úderů na irácké jaderné, biologické a chemické zbraně a 1500 leteckých úderů na odpalovací zařízení řízených střel Scud. Následující americko-britská operace Pouštní liška (Desert Fox) pak znamenala dalších 300 náletů na irácké cíle. Saddámův hazard vyvolal vojenskou odpověd', při které američtí a britští piloti nakonec zničili dokonce více iráckých ZHN, než se původně čekalo. Během relativně krátké války v Perském zálivu byl vážně poničen vojenský ale i průmyslový potenciál země. Byly poničeny elektrárny, rafinérie, ropné zdroje, sklady potravin, úpravny pitné vody, čističky odpadních a další důležité objekty, některé charakteru ODOS. Navíc po válce následovaly ekonomické sankce, které měly těžké důsledky pro obyvatelstvo. [11] Tím, že byly narušeny objekty průmyslové infrastruktury, které byly spojeny s chemickými výrobami, či používajícími chemické látky ve svých výrobách, bylo možné předpokládat vznik chemických havárií. Ty jsou obecně definovány jako havárie (destrukce) zařízení infrastruktury určitého území, spojené s únikem průmyslových chemických látek (PCHL) do okolí v množství, které vážně ohrožuje osoby nebo životní prostředí. [12]

\subsection{Válka v Afghánistánu 2001 - operace Trvalá svoboda}

Tato operace je považována za třetí velkou válku USA, kterou vedly v době od skončení studené války (od počátku 90. let). Jejím spouštěčem se staly teroristické útoky dne 11. září 2001, které od samého základu změnily nejenom chování USA, ale podstatu mezinárodních bezpečnostních vztahů na globální úrovni. Již z charakteru operace, to znamená naplnění hlavního cíle, a to eliminace bezpečnostních hrozeb souvisejících s teroristickými aktivitami al-Ká'idy za výrazné podpory Talibánu, který ji poskytoval zázemí a nebyl ochoten proti ní zasáhnout, vyplývá, že USA se snažily maximálně zefektivnit přesnost naváděné munice. Tím se USA snažily vyhnout dvěma hlavním rizikům - riziku nepřesných leteckých úderů a riziku nákladnosti vzdušných operací. Odlehlost afghánského území se totiž projevila jako velice problematická. Nasazením přesně naváděné munice se výrazně snížila rizika ztrát na životech civilního obyvatelstva a škod na civilní infrastruktuře nezbytné pro život Afghánistánu po skončení války. Zvýšení přesnosti z $10 \%$ na $90 \%$ v porovnání s operací Pouštní bouře se výrazně snížilo riziko vzniku chemických havárií na území Afghánistánu.

\subsection{Operace Irácká svoboda 2003}

Tzv. druhá irácká válka byla další etapou ve složitém vývoji vztahů mezi USA a Irákem. Byla také výsledkem toho, co se mezi těmito dvěma zeměmi stalo během dvanáctiletého období po skončení operace Pouštní bouře. Po etapě zadržování, která byla typická pro osmileté období prezidenta Billa Clintona, přišla administrativa G. W. Bushe. Ta se stále více orientovala na vojenské řešení problémů v Iráku. Na Saddáma Husajna byl vyvíjen sílící mezinárodně politický tlak, jehož základem byla rezoluce Rady bezpečnosti Organizace spojených národů (OSN) č. 687, která se zaměřila hlavně na irácké ZHN. [13] Tlak na vojenské svržení Saddámova režimu tedy zesílil po volebním vítězství 
G. W. Bushe a po nástupu D. Rumsfelda do funkce ministra obrany. Zcela zásadním mezníkem se však stalo 11. září 2001. Po tomto datu nastala etapa př́ípravy vojenského řešení iráckého problému. $V$ jejím průběhu se shromažd’ovaly argumenty ve prospěch dvou zásadních tezí:

$\square$ Saddám byl zapleten do teroristických útoků,

$\square$ Saddám vlastní silný arzenál ZHN a chystá se jej použít proti USA a jejich spojencům.

Operace Irácká svoboda skončila zcela jasným vítězstvím USA. Byl znovu potvrzen obrovský náskok amerického vojenství nad celým světem, včetně ostatních členských zemí NATO. [14] Tuto myšlenku potvrzuje i autor, [15] který uvádí, že ,zánik bipolarity rovněž umožnil vytvoření predominantního postavení USA při řešení bezpečnostních problémů na globální úrovni. Soudobý diplomatický, vojenský, technologický, ekonomický i hospodářský potenciál Spojených států umožňuje provádění relativně samostatné bezpečnostní politiky na globální úrovni. V praxi tak funguje asymetrický model mezinárodních vztahů“. Ze studia dokumentů hodnotících operaci vyplynuly určité teze, které tuto nadvládu USA charakterizují. Z hlediska chemického vojska (CHV) Armády České republiky a rozvoje jeho specializovaných schopností se v zásadě jedná o trvalý rozvoj úrovně a spolehlivosti specializovaných sil CHV AČR, a to jak pro získávání přesných údajů o rozvoji radiační, chemické a biologické situace, tak i o rozvoj schopností plnit odborné úkoly v podmínkách kontaminace způsobené klasickými ZHN, ale i kontaminace vzniklé po únicích PNL. Operace Irácká svoboda tedy naznačila, že význam vysoce připravených speciálních sil uskupených do malých, účelově vytvářených úkolových uskupení, bude nadále stoupat.

Za přínosy celosvětového významu lze považovat to, že operace s akcentem na boj proti šíření ZHN byla vedena plně v souladu s rezolucí Rady bezpečnosti OSN číslo 1441 ze dne 20.12.2002 i přesto, že toto stanovisko zastávaly pouze USA. Jinak se o legalitě Operace irácká svoboda vedly dlouhé hádky a spory. Tato rezoluce řekla, že šíření ZHN představuje hrozbu pro mezinárodní bezpečnost, kterou nelze podceňovat. [16] Nedílně s tím však zvýraznila nezbytnost dvou klíčových faktorů: přesvědčivých důkazů a v návaznosti na ně pak jasného mandátu Rady bezpečnosti OSN.

Za zmínku stojí také negativa, která operace Irácká svoboda přinesla. Ta se především projevila ve změně charakteru této asymetrické operace, přičemž tento pojem je nutno chápat jako ozbrojený konflikt, při kterém proti pravidelným ozbrojeným silám působí protivník, jenž je nesrovnatelný z hlediska cílů, metod, prostředků vedení boje a výzbroje. Asymetričnost se projevuje v tom, že pravidelné ozbrojené síly vedou bojovou činnost podle pravidel vyjádřených doktrínami, kdežto protivník používá metody, které jsou často v rozporu s mezinárodním humanitárním právem i s obecně uznávanými etickými a mravními zásadami. Proti takovému protivníkovi se používají metody boje, které musí reagovat na zvláštnosti jeho netradičního působení. [17, 18] Negativa této operace se neprojevila pouze v rovinách vojenských, politických, ekonomických, sociálních, ale i psychologických. Zmíním pouze dvě z nich, a to rovinu politickou a psychologickou. Vojenská intervence do Iráku byla v USA kritizována především z následujících důvodů:

1. Saddám Husajn v minulosti nasadil ZHN (v roce 1984) a USA reagovaly rozpoutáním válečného konfliktu až 19 , resp. 15 let poté. 
2. Operace Irácká svoboda byla odůvodněna neochotnou nebo neschopností Iráku prokázat zničení arzenálů ZHN. Ten se stal se pověstným odmítáním spolupráce s OSN a ostentativním porušování rezolucí Rady bezpečnosti OSN č. 715, 778, 949, 1060, 1115, 1134, 1137, 1205, 1441.

3. Existence iráckých ZHN na počátku 21. století byla postavena nikoliv na faktech, ale na domněnkách a myšlenkových konstrukcích. I když použití ZHN je faktem, nejasnosti panovaly ohledně osudu jejich arzenálu. Pokud by Husajn ZHN měl, pak ne proto, aby je použil k útoku, nýbrž k tomu, aby se stal nenapadnutelným. Eichler cituje z díla Walt St: An Unnecessary War, které bylo napsáno J. Meareheimerem takto: „Pokud vyděrač a jeho cílový stát mají ZHN, pak je vydírání nemožné, protože vydírající by nasazením těchto zbraní [jaderných, pozn. autora] přivolal svoje vlastní zničení. V prrípadě Iráku je ale zřejmé, že ZHN opakovaně použil k útoku, kdy mu nasazení chemických zbraní umožnilo úspěšnou ofenzivu a definitivní převzetí iniciativy. Zároveň aktivně používal ZHN vůči vlastnímu civilnímu obyvatelstvu." [19]

Po rychlém a neobyčejně snadném vítězství invazních vojsk se s překvapivou rychlostí změnil poměr sil i oblasti vedení psychologické války. Mezi ty zvláště závažné patřila ta skutečnost, že válka byla vedena podle ne př́liš jasného mandátu (z hlediska legality) a s diskutabilní legitimitou. Sporná legalita operace spočívala v různém výkladu rezoluce Rady bezpečnosti číslo 1441 . V ní je tato klíčová věta: „Rada bezpečnosti opakovaně varuje Irák, že v případě porušování svých povinností (vyplývajících z rezolucí Rady bezpečnosti) se vystavuje vážným důsledkům." Pro koalici (včetně ČR) to byl však dostatečně legální základ pro operaci. Nelegitimita operace se projevila v tom, že se v zásadě nepotvrdily důvody, proč byla rozpoutána. Podle závěrů inspekčních týmů se nenašly ZHN. Pouze dílčí epizodické zásahy specialistů CHV AČR nemohly vytvořit dostatečnou důvěru v prostředky protichemické výbavy jednotlivce, a to zejména ve speciální prostředky individuální ochrany (PIO). I přesto, že specialisté CHV AČR byli nuceni podstoupit zátěž zpo̊sobenou jejich nošením, nebylo možno prakticky potvrdit jejich účinnost, a tím zvýšit důvěru v jejich používání, což speciálně v malých týmech může položit základ ke vzniku bojového stresu a dalších negativních následků z něho vznikajících.

Závěrem k operaci Irácká svoboda je možno uvést, že zásadně problematickým se stalo samotné zdůvodňování vojenského zásahu v Iráku. Nejprve se hovořilo o iráckém arzenálu ZHN jako o naléhavé bezpečnostní hrozbě pro USA a jejich spojence. Tento důvod byl navíc o to závažnější, že již v roce 1992 Rada bezpečnosti OSN prohlásila proliferaci ZHN za hrozbu mezinárodnímu míru. Pokud by se tedy a to nejenom v případě Iráku, ale kteréhokoli jiného státu takové podezření prokázalo, pak by to byl mezinárodněprávní podklad pro zásah mezinárodního společenství. Argumenty o iráckém arzenálu ZHN dále ukázaly, že záměrné nadsazování při vyhodnocování bezpečnostních hrozeb může být dvojsečnou zbraní.

\section{Klíčové bezpečnostní dokumenty USA}

Řešení situace vzniklé po teroristických útocích na cíle v USA leželo plně na bedrech americké administrativy. Lidé, pod silou silných emocí zpo̊sobených jednak značnou katastrofou na straně jedné a značnou medializací samotných událostí, žádali pokud 
možno okamžitá politická a vojenská řešení. Ta však nebylo možné udělat okamžitě, tedy bez patřičné politické opory. Ta je dána zejména přijetím zásadních strategických vojensko-politických dokumentů.

Politická reprezentace USA proto vyvíjela všechny aktivity proto, aby argumenty, které byly uvedeny výše, byly naplněny, a to alespoň na teoretické bázi. Ačkoli v př́ípadě prvního argumentu byl důkaz relativně evidentní (pád newyorských Dvojčat), v př́ípadě toho druhého bylo nutné všechny zprávy vyhodnocovat tak, aby tomuto zadání odpovídaly co nejvíce. Vyvrcholením tohoto přístupu k iráckým ZHN se stalo Rumsfeldovo vyjádření, že nedostatek důkazů o těchto zbraních není důkazem, že tam skutečně nejsou - ,absence of evidence is not the same as evidence of absence”. [20] Je tedy zrrejmé, že americký přístup ke hrozbě proliferace ZHN vstoupil do nové etapy.

Tři měsíce po teroristických útocích prezident Bush ve svém zásadním projevu vyhlásil, že rogue states (problémové státy) jsou nejpravděpodobnějším zdrojem chemických, biologických a jaderných zbraní pro teroristy. [21] A nová národní bezpečnostní strategie (national security strategy) ze září 2002, která posléze dostala název Bushova doktrína, již přímo vyhlásila odhodlání v případě potřeby ,jednat preemptivně, a to s cílem eliminovat tuto hrozbu pro USA nebo jejich spojence a přátele“. [22] Bushova doktrína výrazně profilovala USA ve vztahu ke hrozbám terorismu a šíření ZHN, které považovala za nejnaléhavější a nejvážnější bezpečnostní hrozby globálního charakteru. Ostatně odhodlání zabránit nepřátelům, aby se zmocnili ZHN, a tak ohrožovali USA nebo jejich spojence je jeden ze strategických zájmů USA na počátku 21. století. Strategie položila rozhodující důraz na prevenci pojímanou jako nový přístup USA k bezpečnostním hrozbám současného světa a za cíl USA vyhlásily udržení stávající vojenské převahy nad zbytkem světa, a to na neomezeně dlouhou dobu. Ve strategii se tedy odrazil velký posun bezpečnostně-politického myšlení v USA v relativně krátké době po nástupu administrativy G. W. Bushe. [23] Výsledkem tohoto posunu se stalo „expanzivní přehodnocení americké bezpečnosti doprovázené radikální změnou amerického přístupu k aliancím“, [24] což se velice pozitivně projevilo v rozšiřování NATO v následujících letech. V relativně nedávné době vstoupila v platnost národní bezpečnostní strategie schválená v roce 2006. Národní bezpečnostní strategie je hodnocena jako dokument přelomového charakteru a jednoznačně stanoví, že bezpečnostní hrozby spojené s případným použitím ZHN jsou velmi vážné a naléhavé a obsahují potenciál škod nedozírných následků.

Při stanovení priorit boje proti mezinárodnímu terorismu Bushova administrativa v roce 2002 rozdělila státy usilující o vybudování vlastních jaderných potenciálů do dvou skupin. Do první skupiny byly zařazeny státy jako Izrael, Indie a Pákistán, které byly de facto proliferátory a nebyly jim přisuzovány nepřátelské záměry ve vztahu k USA. Do druhé skupiny byly zařazeny státy jako Irák, KLDR, a Írán, které byly pojmenovány nepřátelskými proliferátory a byly jim přisouzeny agresivní záměry ve vztahu k USA. Na základě této předpovědi hrozby nepřátelských států byla v prosinci roku 2002 vypracována Národní strategie boje proti šírení ZHN (National Strategy to Combat Weapons of Mass Destruction). [25] Její výchozí tezí je obava, že existují nebezpečné státy či organizace, které ZHN nechápou jako nástroj nejkrajnějšího řešení, ale jako nástroj, který by jim sloužil k vyvažování konvenční převahy USA. Strategie dále jasně stanovuje, že boj proti nepřátelským proliferátorům bude spočívat na třech pilíř́ch, jimiž jsou tzv. neproliferační politika (politika nešíření, nonproliferation), aktivní opatření 
proti proliferaci (counterproliferation) a odstraňování následků ozbrojeného konfliktu za použití ZHN. První ze tř́i pilírư strategie USA spočívá především na diplomatickém úsilí s cílem odrazovat dodavatelské státy od spolupráce s proliferátory a tyto státy zase vést k tomu, aby skončily své proliferační programy. Tato politika se bude zaměřovat na vytváření mnohostranných programů a režimů, jejichž smyslem je bránit šíření jaderných, chemických a biologických zbraní a řízených střel jakožto jejich nosičů. Druhý pilîŕ tvoří zákaz šiřrení ZHN, odstrašování a obrana a zmírňování následků v případě konfliktu za použití ZHN. Nosnou a také nejvíce diskutovanou část této roviny americké strategie představuje odhodlání, že na použití ZHN proti USA, proti jejím ozbrojeným silám v zahraničí nebo proti jejich přátelům a spojencům, budou USA reagovat nasazením všech sil, včetně nejkrajnějšího řešení, tedy ZHN. Podoby třetího pilíře by závisely na konkrétním rozsahu použití ZHN. Tato strategie byla přepracována $\mathrm{v}$ roce 2004 a v roce 2006.

Zatímco se ve strategii z roku 2002 se rizika spojená s únikem PCHL nevyskytují, ve strategii z roku 2006 jim je přikládán poměrně značný význam. Je v ní uvedeno, že opatření pasivní ochrany zahrnují nejenom opatření k minimalizaci nebo eliminaci zranitelnosti dopadů použití ZHN proti USA, jejím partnerům, spojeneckým ozbrojeným silám, americkým zájmům a zařízením kritické infrastruktury, ale také zvládání opatření směřujících ke snížení účinků PCHL na území USA i v zahraničí. Dále jsou v této strategii rozebrána opatření tzv. consequence management, která jsou směřována k přijímání opatření vedoucích ke snížení vlivů útoků vedených ZHN a při událostech spojených s úniky PCHL. Je v ní stanoveno, že armáda USA musí být na tato opatření připravena, a to nejenom na vlastním území, ale také v zahraničí včetně zabezpečení podpory spojenců a partnerů. Je v ní také poskytnuta definice PCHL, ve které je zmíněna nutnost ochrany sil před jejich účinky, která bude realizována specializovanými prostředky ochrany kůže (povrchu těla). [26] Lze tedy uvést, že strategie je souhrnnou, všeobsáhlou odpovědí na hrozbu, kterou USA považují za nejnaléhavější na počátku 21. století. Její výchozí tezí je obava, že existují nebezpečné státy či organizace, které ZHN nechápou jako nástroj nejkrajnějšího řešení, ale jako nástroj, který by jim sloužil k vyvažování konvenční převahy USA a který by jim navíc dal možnost, jak Spojeným státům znemožnit, aby v oblastech svých životních zájmů zasahovaly v př́ípadě agrese proti jejich přátelům a spojencům. [27]

V otázkách tzv. CBRN terorismu [28] je situace poněkud odlišná. Na svém významu získává kombinace terorismu a jaderných zbraní. Pro ilustraci uvádím srovnání v originálním jazyce tak, jak jsou uvedeny ve zmíněných dokumentech. Za vlády prezidenta Bushe bylo ve strategii z roku 2006 uvedeno: „The gravest danger our Nation faces lies at the crossroads of radicalism and technology." Za vlády prezidenta Obamy se ve strategii objevuje text: „The American people face no greater or more urgent danger than a terrorist attack with a nuclear weapon." [29]

\section{Bezpečnostní dokumenty NATO}

Strategická koncepce NATO upřesňuje svoji vizi, v závislosti na vývoji bezpečnostního prostředí, poslání a úkolech NATO, včetně záměrů použití ozbrojených sil členských států NATO. Tato koncepce je neperiodický dokument, který je aktualizován zpravidla při zásadní změně bezpečnostního prostředí. Koncepce, jejíž zadání bylo 
upřesněno v roce 2009 na summitu ve Štrasburku, vstoupila v platnost v roce 2010, tedy v době, kdy se konal summit NATO v Lisabonu. [30, 31]

V úvodu roku 2010 se i ČR zasadila o vedení diskuzí nad nově vznikající strategickou koncepcí Severoatlantické aliance. V lednu roku 2010 byla v Praze organizována konference, jejíhož jednání se účastnila i československá rodačka a bývalá ministryně zahraničí v Clintonově vládě Madeleine Albrightová. [32] Jedním ze závěrů jednání konference bylo sdělení, že je potřeba se zaměřit na budování lepších vztahů s Ruskem, protože NATO má potvrdit svoji ochotu k budování euroatlantické bezpečnosti založené na široké spolupráci s nečlenskými zeměmi, Rusko nevyjímaje. Dále se účastníci jednání shodli, že NATO si má do budoucna udržet svůj jaderný arzenál. Jakékoli změny v rozmístění nukleárních zbraní, které jsou v Evropě, by mělo být schvalované celou Aliancí. Tyto závěry potvrzují, že tendence ve zvyšování odolnosti nasaditených sil včetně zabezpečení ochrany proti ZHN jsou nadále opodstatněné.

O vypracování souhrnné politické směrnice, [33] která vychází ze strategické koncepce NATO vydané v roce 1999, rozhodli nejvyšší představitelé členských států NATO na summitu v Istanbulu v červnu 2004. Směrnice byla schválena Severoatlantickou radou na úrovni velvyslanců ke konci roku 2005. Na summitu v Rize v listopadu 2006 bylo přijetí směrnice oficiálně stvrzeno nejvyššími představiteli aliančních zemí a současně bylo rozhodnuto o jejím zveřejnění. Směrnice poskytuje rámec a politické zadání pro pokračující transformaci NATO a na příštích 10 až 15 let definuje priority pro všechny otázky týkající se aliančních schopností. Strategická koncepce NATO z roku 1999 nicméně popsala měnící se bezpečnostní prostředí způsobem, který je nadále platný. Souhrnná politická směrnice charakterizuje bezpečnostní prostředí jako „neustále se měnící, komplexní, globální, s obtížně předvídatelným vývojem. Vývoj mezinárodní bezpečnosti má rostoucí vliv na život obyvatel členských zemí NATO i ostatních států. Nárůst terorismu v globálním měřítku i ničivém účinku a šíření ZHN budou pravděpodobně představovat největší hrozby pro Alianci v příštích 10 až 15 letech. Nestabilita způsobená hroutícími se a zhroucenými státy, regionálními krizemi a konflikty a jejich příčinami a následky, zvyšující se dostupnost sofistikovaných konvenčních zbraní, zneužití nových technologií a narušení toku životně důležitých zdrojů, budou pravděpodobně v tomto období představovat hlavní rizika a výzvy pro NATO. V̌̌echny tyto faktory se mohou navzájem prolínat nebo kombinovat, přičemž nejnebezpečnější kombinací by byl případ, kdy ZHN budou mít ve své výzbroji právě teroristé“. Je v ní zdůrazněno, že je nutno trvale zvyšovat schopnosti NATO předvídat a vyhodnocovat hrozby, rizika a výzvy, kterým čelí, se zvláštním důrazem na hrozby představované terorismem a širrením ZHN. Za nejdůležitější považuji zmínku o „schopnosti vést operace s ohledem na hrozby představované ZHN a chemickým, biologickým, radiologickým a jaderným ohrožením“.

\section{Klíčové bezpečnostní dokumenty EU a rozdílnost jejich chápání v porovnání s americkými bezpečnostními dokumenty}

Irácká krize, operace Irácká svoboda, asymetrická válka, která po ní následovala, a v neposlední řadě i vnitroamerická diskuze měly výrazný dopad i na Evropskou unii. 
Ta se pod vlivem těchto událostí zaměřila na vypracování své vlastní bezpečnostní strategie, která byla pojmenována jako „Bezpečná Evropa v lepším světě - evropská bezpečnostní strategie“ (A Secure Europe in a Better World: European Security Strategy). Javier Solana předložil koncepční dokument a ten potom dne 12. 12. 2003 schválila Evropská rada na úrovni hlav států a vlád.

První kapitola nazvaná Nové hrozby a nové bezpečnostní prostředí potvrzuje základní shodu s USA v tom, že terorismus hodnotí jako hrozbu strategické povahy. Zdůvodňuje to tím, že tento nanejvýš nebezpečný jev je spojen s odhodláním použít neomezeného násilí, ohrožuje lidské životy, že boj proti němu je nákladný a že ohrožuje otevřenost a snášenlivost evropských společností. Odlišnost ve srovnání s USA se projevuje v tom, že Evropa není tak vyhledávaným symbolickým cílem pro akce globální působnosti. Pokud jde o druhou hrozbu, tedy o proliferaci ZHN, EU ji hodnotí velmi podobně jako USA. Považuje ji za nejzávažnější hrozbu mezinárodního míru a bezpečnosti. Z toho vychází její závěr, že nejhroznějším scénářem by byl stav, kdy by se ZHN dostaly do rukou teroristických organizací. EU se s USA shoduje rovněž v závěru, že takový scénář je tím pravděpodobnější, čím rozsáhlejší je jejich proliferace.

Jak již bylo uvedeno výše, terorismus představuje spolu se šířením ZHN v kombinaci s činností diktátorských režimů a tzv. problémových států (rogue states) nejvážnější bezpečnostní hrozby období od ukončení studené války až do současnosti jak pro USA, tak i pro EU. Podle Eichlera [34] se při snaze o jejich eliminaci zvýraznily rozdíly mezi USA a jejich evropskými spojenci i přes vzájemný souhlas s jejich existencí. Vedle prohlubování rozdílů v úrovni vojensko-technického rozvoje jde zejména o bezpečnostní politické přístupy k terorismu jako jedné nejzávaznější bezpečnostní hrozby na počátku 21 . století. Rozdíly se začaly projevovat již v prvních měsících po událostech 11. září 2001, kdy se objevovaly pojmy válka proti terorismu verzus boj proti terorismu. A právě z této relativní nejasnosti významu pojmů vyvstaly otázky, zda se má terorismus posuzovat jako zločin nebo jako forma války se všemi jejími pravidly vyplývajícími z dodržování zásad mezinárodního práva. [35, 36] Studiem evropských bezpečnostních dokumentů jako např. evropská bezpečnostní strategie [37] jsem však dospěl k závěru, že evropské státy nepodceňují nebezpečí terorismu a hrozeb z něho vyplývajícími, ale mají poněkud jiný názor na boj proti němu, a to především z hlediska použitých prostředků pro jeho eliminaci. EU nemá dostatek speciálních operačních sil, prostředků strategického průzkumu, útočných vrtulníků a přesně naváděné munice. V důsledku toho není schopna vést operace související s potíráním terorismu po delší dobu. Na rozdíl od USA však EU dochází k závěru, že žádná z uváděných hrozeb není hrozbou čistě vojenského charakteru, a proto nelze žádné z nich čelit jenom vojenskými nástroji.

Dne 1. prosince 2009 se uzavřel několikaletý proces vyjednávání o institucionálních otázkách. Lisabonská smlouva mění stávající zakládající smlouvy EU, tedy Smlouvu o EU a Smlouvu o založení Evropského společenství, aniž by je nahrazovala. Poskytuje EU odpovídající právní rámec a nástroje pro řešení budoucích výzev a naplnění očekávání občanů. V otázkách bezpečnosti je v ní uvedeno, že „,v dnešním globalizovaném a neustále se měnícím světě se Evropa potýká s novými problémy, jako je globalizace, demografické změny, změna klimatu, potřeba udržitelných energetických zdrojů a nová bezpečnostní rizika. Právě těmto výzvám čelí Evropa v 21. století“. [38] Nejvýznamnější části smlouvy, které se týkají realizace bezpečnostní politiky v otázkách ochrany proti terorismu, lze nalézt v hlavě VII, článku 188r. Ten stanoví, že pokud je některý členský 
stát cílem teroristického útoku nebo obětí přírodní nebo člověkem způsobené pohromy, jednají EU a její členské státy společně v duchu solidarity. EU uvede do pohotovosti veškeré nástroje, které má k dispozici, včetně vojenských prostředků poskytnutých členskými státy, aby:

$\square$ odvrátila teroristickou hrozbu na území členských států,

$\square$ chránila před př́padným teroristickým útokem demokratické instituce a civilní obyvatelstvo,

$\square$ poskytla členskému státu pomoc na jeho území v př́ípadě teroristického útoku, pokud o to požádají jeho politické orgány,

ㅁ poskytla členskému státu pomoc na jeho území v případě přírodní nebo člověkem způsobené pohromy, pokud o to požádají jeho politické orgány.

\section{Současné vnímání hrozeb možného zneužití ZHN a PNL v bezpečnostních a strategických dokumentech ČR}

Jedním z nejvýznamnějších dokumentů, který definuje bezpečnostní hrozby a z něhož vychází i jejich vnímání ústředními orgány státní správy, kterými jsou zejména ministerstvo zahraničních věcí, obrany a vnitra, je tzv. evropská bezpečnostní strategie a souhrnná politická směrnice NATO schválená na konci roku 2005, oficiálně přijata $\mathrm{v}$ roce 2006. Touto problematikou se ale zabývají i další významné dokumenty NATO, případně Organizace pro bezpečnost a spolupráci v Evropě (OBSE). [39]

Mezi nejdůležitější dokumenty, zabývající se bezpečnostní a vojenskou politikou ČR, patř́i:

$\square$ Bezpečnostní strategie České republiky, 2011, [40]

Vojenská strategie České republiky, 2008 [41]

$\square$ Obranná strategie České republiky, 2012 (nahrazuje Vojenskou strategii ČR z roku 2008) [42]

$\square$ Dlouhodobá vize rezortu Ministerstva obrany, [43]

Bílá kniha o obraně. [44]

Minulá Bezpečnostní strategie ČR (2003) považovala za strategickou hrozbu globální teroristické aktivity ve spojení se šířením ZHN a jejich nosičů a zdůrazňovala „privatizaci“ zdrojů hrozeb. Bezpečnost pojímala komplexně od zajištění na úrovni jednotlivého občana až po úroveň celostátní. V dokumentu bylo zdůrazněno, že vláda nemůže připustit, aby bezprostřední a identifikovaná hrozba použití ZHN a PNL přerostla např. v teroristický útok s katastrofálními následky. Tento významný bezpečnostní dokument zároveň charakterizoval bezpečnostní prostředí, které již může být v některých detailech vnímáno, vzhledem k relativnímu ,stáří“ dokumentu, poněkud odlišně. Bylo uvedeno, že OSN neplní svoji stabilizační úlohu, a tudíž není na dnešní výzvy plně připravena. Dále se zde uvádělo, že rozhodnutí přijatá na pražském summitu v listopadu 2002 potvrzují platnost původního poslání NATO, a to vzhledem ke vnímání kolektivní obrany, k adaptaci NATO na nové milníky při vnímání nových hrozeb (terorismu a šíření ZHN apod.).

Ve vztahu k prosazování bezpečnostních zájmů ČR lze uvést, že pokud selže prevence a úsilí o mírové řešení situací, ohrožujících nebo porušujících mezinárodní mír a bezpečnost, zejména v souvislosti s hrozbou teroristických útoků a šíření ZHN, tak 
se ČR se připojí $\mathrm{k}$ donucovacím prostředkům včetně použití síly v souladu s aliančními či unijními závazky a v souladu s principy Charty OSN.

ČR se bude nadále zasazovat o prohlubování a přispívat k zefektivňování procesů a mechanismů odzbrojení, kontroly zbrojení, nešíření ZHN, obchodování s vojenským materiálem, radioaktivním materiálem, zbožím a technologiemi dvojího užití a zbraněmi. Bude důrazně podporovat přijetí nových opatření v souvislosti s bojem proti terorismu.

Ozbrojené síly ČR se budou nadále specializovat zejména na výstavbu jednotek (útvarů) a na zvyšování jejich schopností v oblasti ochrany před účinky ZHN, v níž v rámci NATO ČR plní již nyní vedoucí roli. ČR trvale chápe svou specializaci jako efektivní řešení nedostatku obranných zdrojů a současně jako př́ležitost k rozvoji oborů, v nichž má zájem o dosažení a udržení špičkové úrovně.

V současné době platná Bezpečnostní strategie České republiky (2011) uvádí, že významnou roli při zajištování bezpečnostních zájmů ČR sehrává diplomatická služba, a to zejména prostřednictvím rozvíjení dobrých bilaterálních vztahů a spolupráce a působení v mezinárodních organizacích se zaměřením na sběr informací, předcházení krizím a stabilizování krizových oblastí, podporu transformačních a demokratizačních procesů a na spolupráci v boji proti terorismu a nešírení ZHN. Jsou stále zaznamenávány aktivity spojené s významným růstem vojenských kapacit vybraných států včetně ZHN a jejich nosičů, rostoucí poptávkou po klíčových surovinách, aktivitou na finančních trzích, soupeřením o vliv ve strategických oblastech a agresivnějším prosazováním jejich politických ambic na mezinárodních fórech. Trvale platným faktem je to, že někteří státní i nestátní aktéři usilují otevřeně či skrytě o získání tohoto, vysoce nebezpečného typu zbraní. Šíření těchto prostředků může mít závažné důsledky pro bezpečnost v euroatlantickém prostoru. Je proklamováno, že ČR se nadále bude zasazovat o prohlubování a zefektivňování procesů a mechanismů odzbrojení, kontroly zbrojení, k čemuž přispívají některá specifická pracoviště, mezi něž například patří Ústav ochrany proti ZHN Univerzity obrany. Toto pracoviště se zasazuje o rozvoj specializace ozbrojených sil na oblast ochrany proti ZHN.

Vojenská strategie ČR (2008) byla ve své době výchozím dokumentem pro výstavbu a použití ozbrojených sil ČR. Rozpracovala principy obranné politiky, definované v Bezpečnostní strategii ČR. Představuje soubor základních principů zajištování obrany ČR a zásad výstavby a použití ozbrojených sil ČR. [45]

Poslední vydání Vojenské strategie bylo realizováno v roce 2008. Dokument tohoto znění byl v pořadí již čtvrtým v novodobé historii ČR. První z nich byla vydán v roce 1997 (v té době ovšem ještě pod názvem „Národní obranná strategie ČR“), druhý $\mathrm{v}$ roce 1999, třetí potom $\mathrm{v}$ roce 2002 a předposlední v roce 2004. Ve všech uvedených strategiích byly uváděné hrozby zmiňovány, avšak v různém rozsahu a intenzitě. Byly rozpracovány všeobecné zásady ochrany proti účinkům ZHN, zejména v oblasti zvyšování trvalé připravenosti jednotek, útvarů a svazkủ čelit hrozbám, souvisejícím s jejich použitím. Již v té době tedy bylo zdůrazňováno, že všechny jednotky, útvary a svazky musí mít schopnost účinné ochrany proti účinkům ZHN.

Za zmínku stojí, že ve Vojenské strategii ČR z roku 2002 (zpracovávané v období po teroristických útocích na „newyorská Dvojčata“) je již evidentní tendence směřování k ochraně proti účinkům ZHN, a to zejména ve vztahu k teroristickým a odzbrojovacím aktivitám, která se objevuje prakticky ve stejném pojetí i ve strategiích následujících. 
Jejich pořadí se částečně mění, nicméně důraz, položený na hrozbu možného zneužití ZHN a PNL, je v ní patrný.

Obranná strategie České republiky ze září roku 2012 představuje záměr vlády ČR k zajištění obrany ČR v tomto desetiletí. Je v ní rovněž patrný posun ve vnímání bezpečnostních hrozeb. Není v ní totiž zmiňován terorismus ani v jedné z jeho podob. V oblastech týkajících se ochrany proti ZHN zmiňuje nutnost rozvoje specializace sil v oblastech s vyšší přidanou hodnotou, jako jsou například již zmíněné otázky týkající se ochrany proti ZHN. Je však velmi intenzivně zmiňována nutnost trvalé připravenosti na vojenské operace určené k reakci na náhlé a nepředvídané události, mezi něž mohou patřit např. pandemie, pohromy přírodního či antropogenního původu apod. V rámci těchto operací ozbrojené síly ČR mohou podpořit civilní orgány na území státu v rámci integrovaného záchranného systému (IZS) ČR, zejména při zvládání následků rozsáhlých živelních pohrom, průmyslových nebo ekologických havárií. Aby byli specialisté CHV AČR schopni naplnit požadované schopnosti, tak musí být vybaveni takovými PIO, které jim zabezpečí maximální ochranu jejich zdraví před účinky toxických látek.

Dlouhodobá vize rezortu Ministerstva obrany je dokumentem, který by měl být vnímán všemi vojenskými profesionály, ale i ostatními př́íslušníky rezortu MO, jako plánovací dokument „nejvyššího řádu“. Je zpracována jako dokument s relativně dlouhodobým výhledem, který je chápán v rozmezí 20 let. Nutno říci, že jeho vydání bylo dlouhodobě a s velkými nadějemi očekáváno a v závěru roku 2008 ve vztahu k veřejnosti konečně naplněno. Vize rozpracovala do té doby platné výše zmíněné dokumenty (strategie) a je nutno ji vnímat jako základní podklad pro zpracování následných plánovacích dokumentů, strategií výstavby a použití druhů vojsk a služeb a - v neposlední řadě - také pro plánování nákladů a výdajů na obranu.

Pro rozvoj schopností CHV AČR se stala zcela zásadním dokumentem Strategie ochrany proti zbraním hromadného ničení rezortu MO, [46] který byl v roce 2007 schválen ministryní obrany Vlastou Parkanovu. Ochrana proti chemickým, biologickým, radiologickým a jaderným zbraním nebo proti účinkům nebezpečných látek uvolněných při průmyslových haváriích, přírodních katastrofách nebo možných teroristických útocích, má z hlediska aktuálního stavu i předpokládaného vývoje bezpečnostní situace mimořádný význam jak v rámci zajišt'ování obrany teritoria ČR, tak při působení ozbrojených sil ČR v zahraničních operacích. Při definici hrozeb vychází ze souhrnné politické směrnice a z poslední strategické koncepce NATO.

Př́ definici hrozeb se odvolává na dokument vojenského výboru NATO, [47] který plně respektuje jejich specifikaci uvedenou ve strategických dokumentech Severoatlantické aliance. Strategie ochrany proti ZHN obecně konstatuje, že existují tři zdroje možného ohrožení ZHN či PNL:

- Použití ZHN by přineslo strategický efekt jen při skutečně rozsáhlém a masovém nasazení, jehož př́ípravy by bylo velmi obtížné utajit. Přes existenci mezinárodní Úmluvy o zákazu chemických zbraní však ve světě nadále existují značné kapacity $\mathrm{k}$ jejich výrobě a značné deklarované zásoby látek, které podléhají Úmluvě, ale které nebyly přes ustanovení Úmluvy dosud zlikvidovány. Doposud však nejsou indikace, že se některá současná armáda připravuje na masové použití chemických zbraní v rámci př́ípadného konfliktu a pravděpodobnost jejich použití je velmi nízká. 
- Uvolnění PNL v důsledku havárie, prŕírodní katastrofy nebo teroristického útoku, představuje reálnou potenciální hrozbu pro operující síly i obyvatelstvo, zejména ve vyspělých průmyslových zemích a na teritoriích, kde jsou dislokována zařízení zpracovávající nebo produkující PNL. Riziko jejich uvolnění se obecně týká zejména chemických a biologických průmyslových provozů, skladišt' nebo laboratoří. Rozsáhlejší uvolnění průmyslových nebezpečných (biologických, chemických či radioaktivních) látek může kromě př́imých účinků na postižené osoby vyvolat závažné sociální a ekonomické důsledky.

- Použití ZHN a PNL teroristy je v současné době považováno za největší globální bezpečnostní hrozbu. Použití ZHN a PNL teroristy je mimořádně závažné nebezpečí zejména pro civilní populaci. Přes relativně snadnou dostupnost nebo př́pravu toxických a biologických prostředků je však jejich uchovávání, transport a použití zpravidla mimořádně komplikované a „teroristického efektu“ lze zpravidla dosáhnout mnohem snadněji použitím klasických trhavin. Jako relativně nejpravděpodobnější se jeví použití vysoce toxických látek s okamžitým účinkem. Nicméně nelze vyloučit i použití nebezpečných radioaktivních nebo biologických látek, majících dlouhodobě skryté účinky.

Strategie ochrany proti ZHN dále definuje úkoly, které je nutno plnit v rámci zvláštních opatření proti ZHN. V oblasti ochrany osob a materiálů před účinky ZHN či PNL stanovuje úkol zabezpečit rezort obrany odpovídajícími PIO v závislosti na plněných operačních úkolech. V oblasti odstraňování následků použití ZHN a vzniku průmyslových havárií je nutné zabezpečit AČR odpovídajícími prostředky ochrany osob schopnými odolávat i PCHL v kapalném stavu a mít schopnost napomáhat v rámci ČR vybudováním a udržováním sil a prostředků pro odstraňování následků. Rozvoj tedy bude nadále nutné směřovat $\mathrm{k}$ tomu, aby byly zdokonaleny schopnosti plnit úkoly operací v rámci IZS ČR při řešení krizových situací spojených s napadením ZHN, úniky PNL, rizikových biologických agens a toxinů a při výskytu závažných infekčních onemocnění, včetně výpomoci v rámci NATO v jeho zájmových teritoriích. V otázkách zaměření výzkumu bude nutno, z hlediska řešené problematiky, zvyšovat účinnost a dlouhodobou snesitelnost prostředků individuální a kolektivní ochrany před působením radioaktivních kontaminantů, vojensky významných toxických látek a bojových biologických prostředků včetně zavedení nových metod kontroly jejich funkce a spolehlivosti.

Velmi očekávaným a v současnosti velmi často zmiňovaných a diskutovaným dokumentem je Bílá kniha o obraně. Ta mezi hlavní zdroje hrozeb mimo jiné zařazuje i šíření ZHN a jejich nosičů, o kterých se Obranná strategie České republiky nezmiňuje. Ve své obecnosti pracuje prakticky se stejnými informacemi jako výše zmíněné bezpečnostní a strategické dokumenty, které však rozpracovává do větších podrobností. Tu lze spatřovat zejména v tom, že specializace ochrany proti ZHN se má prosazovat u všech jednotek, a to již od stupně družstvo, jejichž PIO musí sehrávat zásadní ochrannou úlohu. Je důležité zmínit, že v tomto dokumentu CHV AČR našlo významnou podporu při naplňování schopností v rámci ochrany proti ZHN preferencí nákupu materiálu a techniky pro své jednotky a útvary. Tyto jednotky a útvary Bílá kniha o obraně zařazuje mezi jednotky, které v přištích pěti letech budou dosahovat vysokou přidanou hodnotu rámci této vysoce odborné specializace. Schopnost ochrany proti ZHN jako svou specializaci má být rozvíjena Centrem ochrany proti ZHN, Aliancí certifikované jako Joint CBRN Defence Centre 
of Excellence, s nímž má Ústav ochrany proti ZHN má uzavřenou dohodu o spolupráci schválenou ředitelem centra a rektorem-velitelem Univerzity obrany.

Podle výše zmíněných dokumentů, které jsou seřazeny podle jisté logické návaznosti jednoho na druhý, lze konstatovat, že ZHN a PNL jsou stále podstatnou a závažnou hrozbou. Z hlediska řešené problematiky byly vyhodnoceny následující oblasti, které podle jejich názoru nejvýznamnějším způsobem determinují a v budoucnu ještě zásadně ovlivní vývojové tendence v oblasti CHZ, ochrany proti ZHN a také CHV AČR, které je určeno k plnění jejich nejsložitějších úkolů:

- Prevence a příprava na nepředvídatelné živelní, ekologické či průmyslové havárie a katastrofy, včetně prevence a přípravy na nepředvídatelný vznik a šíření nakažlivých smrtelných chorob. V této oblasti se CHV může podílet na zabezpečování pitné a užitkové vody, dekontaminace civilních osob, budov, terénu apod. v postižených oblastech, a to jak pro zasahující jednotky IZS, tak i pro civilní obyvatelstvo, a to vše s využitím svého speciálního vybavení.

- Terorismus, zejména ve vztahu k ZHN a PNL. Č́st specialistů CHV, především jednotky radiačního, chemického a biologického průzkumu, odběru a transportu vzorků, bude nutné připravit a vycvičit na plnění úkolu v EOD/IOD týmech při likvidaci munice a improvizovaných výbušných zařizení, plněných bojovými chemickými látkami nebo jinými nebezpečnými látkami. Významnou úlohu v tomto procesu sehraje vzájemná součinnost se ženijním vojskem AČR.

- Snižování rizika šíření ZHN a obchodu s materiálem, potencionálně využitelným k výrobě „špinavé bomby“ apod. V této oblasti lze podíl vybraných specialistů CHV spatřovat při provádění odběru a analýzy kontaminovaných (podezřelých) vzorků v rámci součinnosti s Policií ČR a základními složkami IZS ČR využitím laboratoří ve výbavě CHV AČR nebo dalších vojenských (civilních) zařízeních. Dále by mohli být specialisté CHV AČR využiti v rámci asistence při provádění kontrol neoprávněného obchodování (černého obchodu) v rámci prevence nárůstu organizovaného zločinu zaměřené na vyhledávání materiálu potencionálně využitelného k výrobě radiologické zbraně, jeho př́padné identifikace a stanovení ve spolupráci s Celní správou ČR a speciálními laboratořemi.

- Možnost použití ZHN na území ČR teroristy nebo za války. Tato oblast bude vyžadovat výcvik a zdokonalení v opatřeních ochrany proti ZHN a CHZ, cílenou přípravu štábů a jednotek, udržování jejich součinnost a akceschopnosti při zásahu s orgány IZS ČR z hlediska zvyšování jejich připravenosti k odpovídající reakci na útoky teroristů nebo použití ZHN v průběhu válečného konfliktu, byt's velmi malou pravděpodobností.

- Vědecko-technický rozvoj CHV AČR. Ten se musí zaměřit na rozvíjení schopností k identifikaci nových druhů chemických zbraní, možností jejich dekontaminace, dozimetrické a chemické kontroly, odběru vzorků, zdokonalování prostředků individuální a kolektivní ochrany, budování schopnosti působit v integrovaném informačním prostředí NEC (Network Enabled Capabilities) apod.

- V oblasti zabezpečení prrípravy velitelů, štábů a jednotek CHV AČR bude muset CHV AČR brát v úvahu řadu dalších dosud opomíjených úkolů a faktorů v návaznosti na ryze odbornou přípravu, zaměřenou na zvládnutí teorie a zásad vedení asymetrických operací, s důrazem na místo a úlohu CHV v nich, výcviku v plnění úkolů CHZ a zajišt'ování ochrany proti ZHN v městských aglomeracích, 
minimalizaci škod na lidských životech a průmyslové infrastruktuře, včetně podílu na odstraňování následků použití ZHN a úniků PNL.

Z uvedeného výčtu dokumentů, zejména z jejich částí, týkajících se hrozeb souvisejících s použitím ZHN a úniků PNL, je patrná evidentní snaha vlády ČR působit v integrovaném informačním prostředí, snaha představitelů ministerstev zahraničních věcí a obrany neopomenout hrozby, týkající se jejich použití či spíše zneužití. Přri studiu dokumentů jsem však zaznamenal jistý posun k postupnému vytlačování těchto hrozeb na „spodní“ místa uváděných výčtů, a tím jako by snižování jejich významu. Na druhou stranu ale patrně nelze očekávat, alespoň v blízké budoucnosti, jejich trvalé opomenutí. Jako příklad posunu ve vnímání hrozeb lze uvést vyjádření vysokého představitele EU pro společnou zahraniční a bezpečnostní politiku (bývalého generálního tajemníka NATO) Javiera Solany, které pronesl těsně před zahájením předsednictví ČR EU. Doslova řekl: "The European Union needs to plan not only for the threats of terrorism and proliferation of weapons of mass destruction, but newly also for the threat of cyber attacks.” [48] Text lze volně přeložit jako „EU potřebuje být připravena nejenom na hrozby terorismu, ale také na hrozby kybernetických útoků”.

\section{Hrozba nekonvenčního terorismu}

Jak již bylo uvedeno výše, po 11. září 2001 se vzedmula vlna apokalyptických úvah o hrozbě nekonvenčního terorismu. [49] Velmi rozsáhle se ve světě, ale především v USA diskutuje o tom, že al-Ká'ida nebo jiná teroristická sít by mohla použít ZHN. Tyto diskuze jsou na jedné straně velmi znepokojivé a alarmující, protože se týkají velmi vážného námětu, ale na straně druhé jsou však do značné míry zavádějící, protože vychází nikoli z ověžených skutečností, jako tomu bylo např. během studené války, kdy se vědělo jaké zbraně má nepřítel. Vychází tedy především z domněnek, obav a předpokládaných dramatických důsledků.

Každý, kdo chce použít ZHN si musí být ujasnit následující základní otázky:

$\square$ Jaké jsou cíle, na které chce udeřit? Jde zejména o to, zda budou vybrány cíle politického nebo hospodářského významu.

Typ látky, která se přitom užije? Z arzenálu chemických zbraní se jako nejdostupnější jeví látky používané v průmyslu a zemědělství. Poměrně neomezené jsou rovněž možnosti použití biologických prostředků, které mohou způsobit epidemická onemocnění.

$\square$ Způsob použití ZHN? Přičemž je potřeba vyřešit zejména otázky jejich přepravy na cíl a způsob efektivního vytvoření smrtelné koncentrace.

口Vytvoření výrobni infrastruktury? Což vždy představuje nejtěžší úkol. Jeho naplnění závisí na naplnění podmínek vědecko-technické kvalifikace, finančních prostředků a znalosti technologických opatření náběhu výroby. První dvě podmínky pravděpodobně nebudou problematické, ale třetí, z hlediska výroby chemických zbraní, kde je potřeba značných prostorů, které jsou dnes snadno zjistitelné a také zasažitelné ze vzduchu, se jeví tato jako těžko splnitelná.

V otázkách řešení vlastní taktiky jde zejména o zvolení formy úderu. Nejčastěji se uvažuje o náletu malého letounu na jadernou elektrárnu nebo objekt, kde se realizuje taková 
výroba, která by mohla způsobit chemickou havárii. Z hlediska soudobých technologií průmyslu se nejčastěji a v největším množství v objektech vyskytují, příp. při požárech by mohly vznikat, tyto zvláště nebezpečné látky PCHL: amoniak, ethylénoxid, fosgen, formaldehyd, chlor, chlorovodík, kyanovodík, methylchlorid, oxid siřičitý, oxid uhelnatý, sulfán, kyselina dusičná, chlorid fosforitý, nitrózní plyny, sirouhlík, oxid sírový, kyselina sírová, fenol, oxid uhličitý, fluorovodík, fosfan aj. Jsou to tedy látky, které jsou vyráběné, zpracovávané, skladované či jinak používané v takovém množství, že jejich únik může způsobit ohrožení zdraví a života lidí a narušit stav životního prostředí. Je pochopitelné, že charakter ohrožení bude záviset na fyzikálně chemických a toxikologických vlastnostech uvedených látek. Z hlediska toxicity, četnosti a množství výskytu nebezpečných PCHL v průmyslových provozech a objektech představují potenciálně největší nebezpečí chlor, amoniak, kyanovodík a formaldehyd. S nebezpečnými škodlivinami se nejčastěji setkáváme v chemických a petrochemických provozech, mohou se vyskytovat i u zimních stadionů, v potravinářských provozech (chladicí zařízení využívající amoniaku), ve vodárenských zařízeních, papírnách a textilních závodech (chlor). Tyto provozy mohou být i nejčastějšími objekty teroristických útoků. [50, 51]

\section{Závěr}

Závěrem lze jednoznačně uvést, že proliferace ZHN, nebezpečí mezinárodního terorismu a možnost kontaktu s PNL na bojišti jsou, podle strategických dokumentů USA, NATO, EU, ČR a CHV AČR, nadále aktuálními hrozbami. Budování schopností specialistů CHV AČR vypořádávat se s nimi v rámci jejich odborné činnosti, a to nejen na území ČR, ale i v mnohonárodních operacích v zahraničí těmito dokumenty není v žádném případě podceňováno ba naopak, je jim přikládám ohromný význam. Rozvoj PIO, který je v dokumentech na národní úrovni zmiňován, je plně opodstatněný a vědecko-výzkumná práce vedená s cílem zjišt’ovat odolnost doposud zavedených speciálních PIO má svoje nezastupitelné místo rámci řešení dílčích úkolů Výzkumného záměru Ústavu ochrany proti ZHN.

\section{Literatura:}

[1] JANOŠEC, Josef a kol. Bezpečnost a obrana České republiky 2015-2025. 1. vyd. Praha: Ministerstvo obrany České republiky - AVIS, 2005. 200 s. ISBN: 80-7278-303-3, s. 20.

[2] EICHLER, Jan. Mezinárodní bezpečnost na počátku 21. století. 1. vyd. Praha: Ministerstvo obrany České republiky - AVIS, 2006, 303 s. ISBN: 80-7278-023-5, s. 86 (dále citováno jako Mezinárodní bezpečnost).

[3] POLACK, Kenneth, M. He's too unreasonable for deterrence. International Herald Tribune, 28.-29. 9. 2002.

[4] Mezinárodní bezpečnost, s. 23-24.

[5] Mezinárodní bezpečnost, s. 42-43.

[6] Pub-36-00-01. Ochrana vojsk: Vojenská publikace. 1. vyd. Vyškov: Institut doktrín VeV-VA, 2009, $127 \mathrm{~s}$.

[7] PITSCHMANN, Vladimír, HALÁMEK, Emil, KOBLIHA, Zbyněk. Boj ohněm, dýmem a jedy - Nejstarší historie použití chemických a zápalných látek a vznik moderní chemické války, Kounice: Military System Line, s.r.o. 2001.

[8] PITSCHMANN, Vladimír. Šamani, alchymisté, chemici a válečníci: kapitoly z dějin chemických, toxinových a zápalných zbraní: období od prehistorie do roku 1914. 1. vyd. Praha: Naše vojsko, 2010, 482 s. ISBN 978-80-206-1110-9. 
[9] PITSCHMANN, Vladimír. Chemici v laboratoři a na bitevním poli: kapitoly z dějin chemických, toxinových a zápalných zbraní: období od roku 1914 do roku 1945. 1. vyd. Praha: Naše vojsko, 2012, 615 s. ISBN 978-80-206-1298-4.

[10] FREEDMAN, Lawrence. War in Iraq: Selling the Threat. Survival, Vol. 46, No. 2, Summer, s. 9.

[11] Mezinárodní bezpečnost, s. 102, 109.

[12] NN 30 0101. Chemické vojsko: Názvoslovná norma. 3. vyd. Praha: Ministerstvo obrany, 2009, s. 47.

[13] Mezinárodní bezpečnost, s. 123.

[14] Mezinárodní bezpečnost, s. 132.

[15] JANOŠEC, Josef a kol. Bezpečnost a obrana České republiky 2015-2025. 1. vyd. Praha: Ministerstvo obrany České republiky - AVIS, 2005. 200 s. ISBN: 80-7278-303-3. s. 21.

[16] Stránky Wikipedia: The Free Encyclopedia [online]. c 2001. United Nations Security Council Resolution 1441. [citováno 2012-11-20]. Dostupné z <http://en.wikipedia.org/wiki/UN_Security_Council_Resolution_1441>.

[17] Doktrína Armády České republiky. Vyškov: Správa doktrín ŘeVD, 2004, 147 s. s. 83.

[18] Stránky časopisu Obrana a strategie [online]. c 2001-2012. Pohledy na asymetrii v operacích. [citováno 2012-12-01]. Dostupné z < http://www.defenceandstrategy.eu/cs/archiv/rocnik-2003/2-2003/ pohledy-na-asymetrii-v-operacich.html $>$.

[19] Mezinárodní bezpečnost, s. 208.

[20] FREEDMAN, Lawrence. War in Iraq: Selling the Threat. Survival, Vol. 46, No. 2, Summer 2004, s 30.

[21] Stránky časopisu Obrana a strategie [online]. c 2001-2012. MAREŠ, Miroslav. Aktéři proliferace zbraní hromadného ničení. [citováno 2012-12-01]. Dostupné z <http://www.defenceandstrategy.eu/cs/ archiv/rocnik-2005/2-2005/akteri-proliferace-zbrani-hromadneho-niceni.html>.

[22] Stránky Information Clearing House [online]. c 2012. The National Security Strategy of the United States of America. [citováno 2009-08-18]. Dostupné z <http://www.informationclearinghouse.info/ article2320.htm>.

[23] Stránky U.S. Department of State [online]. c 2012. The National Security Strategy of the United States of America. [citováno 2012-11-27]. Dostupné z < http://www.state.gov/documents/organization/63562.pdf $>$.

[24] CALLEO, D. W. The broken west. Survival, Vol. 46, No. 3, Autumn 2004, s. 31.

[25] Stránky U.S Department of State [online]. c 2012. National Strategy to Combat Weapons of Mass destruction. [citováno 2012-11-21]. Dostupné z < http://www.state.gov/documents/organization/16092.pdf $>$.

[26] Stránky U.S Department of State [online]. c 2012. National Strategy to Combat Weapons of Mass destruction. [citováno 2012-11-21]. Dostupné z $<$ http://www.state.gov/documents/organization/16092.pdf >.

[27] Stránky Ministerstva obrany $\check{C} R$ [online]. c 2004-2012. EICHLER, Jan. Bezpečnostní strategie USA a EU - shoda i rozdíly. [citováno 2012-11-21]. Dostupné z <http://www.mocr.army.cz/scripts/detail. php?pgid=200>. Vojenské rozhledy, roč. 14, č. 4, str. 3-13.

[28] CBRN zkratka používaná v aliančních dokumentech vyjadřující přídavná jména chemical, biological, radiological, nuclear. V českém jazyce znamená chemický, biologický, radiologický a jaderný. Postupně nahrazuje zkratku ZHN.

[29] Stránky Centra pro sociální a ekonomické strategie [online]. c 2010. LUDVÍK, Jan. Národní bezpečnostní strategie USA. [citováno 2012-11-25]. Dostupné z < http://ceses.cuni.cz/CESES-65-version1NSS2010_Ludvik.pdf>.

[30] Stránky NATO [online]. c NATO. NATO’s new Strategic Concept. Why? How?. [citováno 201211-21]. Dostupné z < http://www.nato.int/strategic-concept/what-is-strategic-concept.html>.

[31] RAŠEK, Antonín. NATO připravuje novou strategickou koncepci. Vojenské rozhledy, 2010, roč. XIX (LI), č. 2, s. 3-21. ISSN 1210-3292.

[32] Stránky Českého rozhlasu [online]. c 1996-2012. KUBECZKA, Josef. Nová strategická koncepce NATO. [citováno 2012-11-21]. Dostupné z <http://www.radio.cz/cz/clanek/123993>.

[33] Stránky Ministerstva obrany Č́R [online]. c2004-2012. Souhrnná politická směrnice. [citováno $2012-$ 11-30]. Dostupné z < http://www.army.cz/scripts/detail.php?id=8463 >.

[34] Mezinárodní bezpečnost, s. 189.

[35] FUCHS, Jiří. Mezinárodní humanitární právo. 1. vyd. Praha: Ministerstvo obrany - AVIS, 2007,230 s. ISBN 978-80-7278-424-0.

[36] CHYLÍK, Josef. Boj podle pravidel. 1. vyd. Praha: Ministerstvo obrany - AVIS, 2008. 121 s. ISBN: nepřiděleno. 
[37] Stránky Centrum für angewandte Politikforschung [online]. c 2009. LINDLEY, Julian, ALGERI, Franco. A European Defence Strategy. [citováno 2009-08-22]. Dostupné z < http://www.cap.unimuenchen.de/download/2004/2004_Venusberg_Report.pdf >.

[38] Stránky portálu Evropské unie [online]. c2012. Lisabonská smlouva. [citováno 2012-11-25]. Dostupné $\mathrm{z}<$ http://europa.eu/lisbon_treaty/take/index_cs.htm>.

[39] OTŘÍSAL, Pavel, KUČÍK, Jozef. Současné vnímání hrozeb možného zneužití ZHN a průmyslových toxických látek v bezpečnostních a strategických dokumentech České republiky. In Sborník př́spěvků z konference „Nové metody a technologie ochrany proti ZHN a průmyslovým škodlivinám “. [CD-ROM] Vyškov: Ústav OPZHN. Univerzita obrany Brno, 17.-18.6.2009. ISBN 978-80-7231-662-5. Adresár: \Paper\Otrisal1.pdf.

[40] Stránky Ministerstva zahraničních věcí České republiky [online]. c2012. Bezpečnostní strategie České republiky. [citováno 2012-12-03]. Dostupné z < http://www.mzv.cz/file/790811/Bezpecnostni_strategie_CR_2011.pdf >.

[41] Vojenská strategie České republiky. 1. vyd. Praha: Ministerstvo obrany - AVIS, 2008. 10 s. ISBN $978-$ 80-7278-483-7.

[42] Stránky Ministerstva obrany České republiky [online]. C2004-2012. Obranná strategie České republiky. [citováno 2012-12-03]. Dostupné z < http://www.mocr.army.cz/images/id_40001_50000/46088/ obrannastrategie-2012.pdf $>$.

[43] LENK, Ladislav. Dlouhodobá vize resortu Ministerstva obrany. A-report, 2008, roč. [neuvedeno], č. 20, str. I-XV. ISSN 1211-801X.

[44] Kolektiv. Bílá kniha o obraně. 1. vyd. Praha: Ministerstvo obrany ČR - odbor komunikace a propagace, 2011, 168 s. ISBN 978-80-7278-564-3.

[45] Doktrína Armády České republiky. Vyškov: Správa doktrín ŘeVD, 2004, 147 str., s. 35.

[46] Čj. 735-51/2007/DP-3691. Strategie ochrany proti zbraním hromadného ničení rezortu MO. Praha, $2007,21 \mathrm{~s}$.

[47] MC 0511. MC Guidance for Military Operations in a CBRN Environment, Including the Potential Military Contribution to NATO's Response to the Proliferation of Weapons of Mass Destruction.

[48] ZAPLETALOVÁ, L., ZÍTKOVÁ, E. Strenghtening EU-NATO Cooperation. Czech Republic Armed Forces Review, 2007, roč. [neuvedeno], č. 2, s. 9. ISSN 1803-2125.

[49] Mezinárodní bezpečnost, s. 174-176.

[50] MATOUŠEK, Jiří, MIKA, Otakar, VIČAR, Dušan. Nové hrozby terorismu: Chemický, biologický, radiologický a jaderný terorismus. [skripta]. 1. vyd. Brno: Ústav OPZHN, Univerzita obrany, 2005. 121 s. ISBN 80-7231-037-2. s. 58.

[51] STŘEDA, Ladislav, BRÁDKA, Stanislav, BLÁHOVÁ Markéta. Nebezpečné chemické látky a ochrana proti nim. 1. vyd. Praha: MV-Generální ředitelství Hasičského záchranného sboru, 2006, 239 s. ISBN 80-86640-63-9.

Obrana vlasti, tedy zajištění vnější bezpečnosti republiky, je jednou z klíčových rolí státu, rolí nepřenositelnou do soukromoprávní sféry. Při formulaci východisek pro efektivní a současně funkční způsob zajištování celistvosti a nedotknutelnosti území a obyvatel republiky je pochopitelně správné nahlédnout do moderní historie a hledat v ní inspiraci, vždyt hrdinství a odvaha československých legionářu stála u vzniku samostatného československého státu a nefalšované vlastenectví Čechů a Slováků bojujících během druhé světové války jak ze Západu, tak z Východu proti nacistickému teroru určitě musejí být vzorem pro českého vojáka jedenadvacátého století. Stejně tak je ale nezbytné se ohlížet po funkčních a fungujících současných armádách podobných zemí (rozlohou i geopolitickou situací), u kterých nedošlo ke čtyřicetiletému přerušení svrchovanosti velení, jako tomu bylo u naší armády, která byla během komunistické diktatury zcela podřízena v rámci tzv. Varšavského paktu velení sovětské Rudé armády.

Jan Vidím, předseda výboru pro obranu Poslanecké sněmovny Parlamentu ČR Obrana vlasti - VIZE 2020

Projev v rámci diskuze v sekci ČR v Evropě a ve světě http://web.ods.cz/kongres/20/projevy-vystoupeni/ prepis $/ 1057 /$ ?sekce $=627 \&$ order $=2 \&$ str $=1$ 